\title{
Characterization and Catalytic Performance of Niobic Acid Dispersed over Titanium Silicalite
}

\author{
Didik Prasetyoko, ${ }^{1}$ Zainab Ramli, ${ }^{2}$ Salasiah Endud, ${ }^{2}$ and Hadi Nur ${ }^{3}$ \\ ${ }^{1}$ Department of Chemistry, Faculty of Mathematic and Sciences, Institut Teknologi Sepuluh Nopember, Surabaya 60111, Indonesia \\ ${ }^{2}$ Department of Chemistry, Faculty of Science, Universiti Teknologi Malaysia, 81310 Skudai, Johor, Malaysia \\ ${ }^{3}$ Ibnu Sina Institute for Fundamental Science Studies, Universiti Teknologi Malaysia, 81310 Skudai, Johor, Malaysia
}

Correspondence should be addressed to Didik Prasetyoko, didikp@chem.its.ac.id

Received 14 May 2008; Accepted 7 August 2008

Recommended by Sridhar Komarneni

\begin{abstract}
Niobic acid, $\mathrm{Nb}_{2} \mathrm{O}_{5} \cdot \mathrm{nH}_{2} \mathrm{O}$, has been supported on the titanium silicalite by impregnation method. The obtained materials were characterized by X-ray diffraction, infrared, and ultra-violet-visible diffuse reflectance spectroscopy, temperature programmed reduction, pyridine adsorption, and field emission scanning electron microscopy techniques. It was demonstrated that the tetrahedral titanium species still retained after impregnation of niobic acid. The results revealed that niobium species interacted with hydroxyl groups on the surface of TS-1. The niobium species in the catalysts are predominantly polymerized niobium oxides species or bulk niobium oxide with the octahedral structure. All catalysts showed both Brønsted and Lewis acid sites. The catalysts have been tested for epoxidation of 1-octene with aqueous hydrogen peroxide. It was found that the presence of niobic acid in the catalysts enhanced the rate of the formation of epoxide at the initial reaction time. Diol as a side product was also observed due to the acidic properties of the catalysts.
\end{abstract}

Copyright ( $) 2008$ Didik Prasetyoko et al. This is an open access article distributed under the Creative Commons Attribution License, which permits unrestricted use, distribution, and reproduction in any medium, provided the original work is properly cited.

\section{Introduction}

Niobium oxides and its compounds are interesting and important materials in catalysis with various functions such as promoter, support, redox materials, and acid catalysts [1$3]$. The materials-containing niobium have been pointed out as effective catalysts in the many processes, for example, dehydration of alcohols, hydrolysis, oxidation, esterification, alkylation, isomerization, and photocatalysis $[1,2,4]$.

Among the niobium compounds, hydrated niobium pentoxide (niobic acid, $\mathrm{Nb}_{2} \mathrm{O}_{5} \cdot \mathrm{nH}_{2} \mathrm{O}$ ) has shown high catalytic activity, selectivity, and stability for acid catalyzed reactions $[5,6]$. The surface acid strength of niobic acid corresponds to the acid strength $(\mathrm{Ho} \leq-5.6)$ of $70 \%$ sulfuric acid. Niobic acid is an unusual solid acid since any kinds of acidic metal oxides show decreasing of the acidic property by absorbing water, while niobic acid shows high acid strength in spite of its water content $[2,7,8]$.

The attachment of niobium oxide over the large surface area of the supports favors the enhancement of the active sites, since the niobium oxide itself exhibits low surface area. The different surface species and catalytic activity produced depend on the support materials, niobium precursors, amount of niobium loading, and the experiment conditions. Jehng and Wachs [9] claimed that the molecular structure of the surface niobium species on $\mathrm{SiO}_{2}$ dependent on the preparation method. They also reported that the surface niobium species on $\mathrm{TiO}_{2}$ gave rise to acidic products. Low amount of niobium oxide loading $(1 \mathrm{wt} \%)$ on silica is predominantly composed of isolated $\mathrm{NbO}_{4}$ units, while the $\mathrm{Nb}$ cations in the supported $\mathrm{Nb}_{2} \mathrm{O}_{5} / \mathrm{SiO}_{2}$ catalysts possess polymerized $\mathrm{NbO}_{x}$ species and/or bulk $\mathrm{Nb}_{2} \mathrm{O}_{5}$ with increasing $\mathrm{Nb}$ loading [10-12]. It has been reported that for supported niobium oxide on silica, both Brønsted and Lewis acid sites remains bound to the support surface even in the presence of water and acts as an effective catalyst for acidcatalyzed reactions [13-17]. We have reported recently in the preliminary study that the surface hydroxyl groups in the titanium silicalite (TS-1) have bounded with niobium species in the $\mathrm{Nb}_{2} \mathrm{O}_{5} / \mathrm{TS}-1$ catalyst [18]. This catalyst is active for 
epoxidation of 1-octene with aqueous hydrogen peroxide. However, the effect of the amount of niobium loading to the catalyst properties and activities has not been studied. This paper reported in detail of preparation, characterization and catalytic performance of niobic acid supported on TS-1, NBA/TS-1.

\section{Experimental}

2.1. Preparation of Sample. Titanium silicalite, $\mathrm{TS}-1(\mathrm{Ti}=$ $1 \% \mathrm{~mol}$ ) was prepared according to the procedure described earlier [19]. Sample Nb/TS-1 with various loading of niobium was prepared by impregnation technique using niobium ethoxide $\mathrm{Nb}\left(\mathrm{OC}_{2} \mathrm{H}_{5}\right)_{5}$ (Aldrich, 99.95\%) precursor. TS-1 was dried in an oven at $200^{\circ} \mathrm{C}$ for 24 hours. After that, the necessary amount of niobium ethoxide was dissolved in $\mathrm{n}$-hexane (Aldrich, >99\%) to obtain the desired metal loading, and the required quantity of a predried TS1 was immediately added to the clear solution with stirring. The mixture was stirred at room temperature for 3 hours. The solid was recovered by evaporating the $n$-hexane at $80^{\circ} \mathrm{C}$. The acid hydrolysis was performed by addition of $20 \mathrm{~mL}$ solution of $0.5 \mathrm{M} \mathrm{HNO}_{3}$ in distilled water and aged overnight, followed by drying at $120^{\circ} \mathrm{C}$. The solid was then washed with distilled water for three times and finally dried at $200^{\circ} \mathrm{C}$ for 24 hours. Sample denoted as $X \mathrm{Nb} / \mathrm{TS}-1$, in which $X$ is the percentage of niobium in wt $\%$.

For comparison on the presence of $\mathrm{Nb}$ species, experiments were carried out to obtain niobium oxide and niobic acid. Niobium oxide was prepared by calcination of ammonium niobium oxalate (99.9\%, Aldrich) at $550^{\circ} \mathrm{C}$ for 3 hours. The prepared particles were labeled as NBO. Niobic acid, $\mathrm{Nb}_{2} \mathrm{O}_{5} \mathrm{nH}_{2} \mathrm{O}$ was prepared by hydrolysis of niobium ethoxide in the neutral hydrolysis method. Niobium ethoxide was first dissolved in the n-hexane and water was then added to this solution drop by drop with stirring and the stirring was continued for an hour. The solid was recovered by evaporation of solvent, followed by drying at $100^{\circ} \mathrm{C}$. Finally, the solid was calcined at $200^{\circ} \mathrm{C}$ for 3 hours and the resulting solid was named as NBA. Table 1 presents the code, niobium content, and preparation method of the samples.

2.2. Characterization. The catalysts structures and properties were determined by X-ray diffraction, Fourier-transform infrared and ultra violet-visible diffuse reflectance spectroscopy, temperature programmed reduction, and pyridine adsorption techniques. All molecularsieves were characterized by powder X-ray diffraction technique for identification of the crystalline phases in the catalysts using a Bruker Advance D8 diffractometer with the $\mathrm{Cu} \mathrm{K} \alpha(\lambda=1.5405 \AA)$ radiation as the diffracted monochromatic beam at $40 \mathrm{kV}$ and $40 \mathrm{~mA}$. The pattern was scanned in the $2 \theta$ range of 5$50^{\circ}$ at a step size $0.020^{\circ}$ and step time 1 second. Infrared spectra of the samples were collected on a Shimadzu Fourier transform Infrared, with a spectral resolution of $2 \mathrm{~cm}^{-1}$, scans 10 seconds, at $20^{\circ} \mathrm{C}$ by $\mathrm{KBr}$ pellet method. The framework spectra were recorded in the region of 1400$400 \mathrm{~cm}^{-1}$. The structure of niobium species in the samples was monitored by UV-vis DR spectroscopy technique. UVvis DR spectra were recorded under ambient conditions on a Perkin Elmer Lambda 900 UV/VIS/NIR spectrometer. The samples were loaded in a quartz cell. The spectra were monitored in the wavenumber range 190-600 nm and KubelkaMunk axis, using polytetrafluoroethylene polymer as a standard background. Temperature programmed reduction experiments were performed using TPDRO 1100 Thermo Quest CE Instrument as follows. The sample (typically about $0.05 \mathrm{~g}$ ) was pretreated in nitrogen at a flow rate of $30 \mathrm{~mL} / \mathrm{min}$ at $200^{\circ} \mathrm{C}$ for 1 hour and cooled down to $100^{\circ} \mathrm{C}$. The reduction analysis was performed by heating the sample from 100 up to $1000^{\circ} \mathrm{C}$ at a rate of $10^{\circ} \mathrm{C} / \mathrm{min}$ and held for 5 minutes at $1000^{\circ} \mathrm{C}$ in a flowing mixture of $5 \%$ hydrogen in nitrogen $\left(\mathrm{H}_{2} / \mathrm{N}_{2}\right)$ at the rate of $40 \mathrm{~mL} / \mathrm{min}$. For hydroxyl groups and acidity study, about $10 \mathrm{mg}$ of sample was pressed at 3 tones for a minute to obtain a $13 \mathrm{~mm}$ disk. The sample was introduced in the infrared cell with calcium fluorite, $\mathrm{CaF}_{2}$ windows. The sample was heated at $200^{\circ} \mathrm{C}$ in vacuum condition for 16 hours. The residual vacuum reached in the IR cell prior to recording spectra was $1 \times 10 \mathrm{e}-6 \mathrm{mbar}$. The infrared spectra were collected at room temperature using Shimadzu 2000 FTIR spectrometer at $2 \mathrm{~cm}^{-1}$ resolution. The types of acid sites were examined using pyridine as a probe molecule. Pyridine was adsorbed at room temperature for a minute, continued by desorption at $150^{\circ} \mathrm{C}$ for an hour. The infrared spectra were recorded at room temperature. Morphology of the solid samples was monitored by field emission scanning electron microscopy technique using electron microscope model Philip XL40.

2.3. Performance of Catalyst. The catalyst performance was tested in the epoxidation of 1-octene using aqueous $\mathrm{H}_{2} \mathrm{O}_{2}$ $(30 \%)$ as oxidant. The reaction mixture containing 1-octene ( $8 \mathrm{mmol}), \mathrm{H}_{2} \mathrm{O}_{2}(8 \mathrm{mmol})$, and acetone $(10 \mathrm{~g})$ as solvent was put in a round bottom flask equipped with a condenser. The catalyst $(0.05 \mathrm{~g}$ TS- 1 based) was then added to the solution. The reaction was carried out in an oil bath under stirring at $70^{\circ} \mathrm{C}$. The products of the reaction were analyzed by a Hewlett-Packard $6890 \mathrm{~N}$ gas chromatograph using an Ultra1 column and a Hewlett-Packard GC-MSD instrument using an HP5 column.

\section{Results and Discussion}

3.1. Catalysts Characterization. In this study, niobium ethoxide was used as a precursor in the preparation of Nb/TS-1. Since the molecular size of niobium ethoxide is larger than the pore size of TS-1, theoretically, the niobium species could not possibly enter the pores of TS-1, thereby should be dispersed on the surface of TS-1 only. In addition, in the preparation of the samples, the acidic condition used in the hydrolysis step to increase the formation of niobic acid, since aqueous solution at $\mathrm{pH}<3$ produced mainly of niobic acid [9].

Figure 1 shows the XRD patterns of the samples. The structure of the samples and the crystallinity of niobium containing TS-1 (based on the highest diffraction line of TS-1) 
TABLE 1: Chemical compositions of the samples and preparation method.

\begin{tabular}{lccc}
\hline Sample & Code & $\mathrm{Nb} /(\mathrm{Nb}+\mathrm{TS}-1), \mathrm{wt} . \%$ & Method \\
\hline Titanium silicalite & $\mathrm{TS}-1$ & $0.81($ gel $)(*)$ & Direct synthesis \\
$\mathrm{Nb}_{2} \mathrm{O}_{5} \cdot \mathrm{nH}_{2} \mathrm{O} / \mathrm{TS}-1$ & $3 \mathrm{Nb} / \mathrm{TS}-1$ & 3.42 & Impregnation \& Hydrolysis \\
$\mathrm{Nb}_{2} \mathrm{O}_{5} \cdot n \mathrm{nH}_{2} \mathrm{O} / \mathrm{TS}-1$ & $10 \mathrm{Nb} / \mathrm{TS}-1$ & 9.92 & Impregnation \& Hydrolysis \\
$\mathrm{Nb}_{2} \mathrm{O}_{5} \cdot \mathrm{nH}_{2} \mathrm{O} / \mathrm{TS}-1$ & $20 \mathrm{Nb} / \mathrm{TS}-1$ & 19.78 & Impregnation \& Hydrolysis \\
$\mathrm{Nb}_{2} \mathrm{O}_{5}$ & $\mathrm{NBO}$ & 100 & Calcination \\
$\mathrm{Nb}_{2} \mathrm{O}_{5} \cdot \mathrm{nH}_{2} \mathrm{O}$ & $\mathrm{NBA}$ & 100 & Hydrolysis \\
\hline
\end{tabular}

${ }^{(*)} \% \mathrm{Ti}=\mathrm{Ti} /(\mathrm{Ti}+\mathrm{Si})$ in the initial gel.

TABLE 2: Structure and crystallinity of samples.

\begin{tabular}{lcc}
\hline Code & Intensity, cps & Structure \\
\hline TS-1 & 1957 & MFI \\
$3 \mathrm{Nb} / \mathrm{TS}-1$ & 1142 & MFI \\
$10 \mathrm{Nb} / \mathrm{TS}-1$ & 942 & MFI \\
$20 \mathrm{Nb} / \mathrm{TS}-1$ & 585 & MFI \\
$\mathrm{NBO}$ & - & Orthorhombic \\
$\mathrm{NBA}$ & - & Amorphous \\
\hline
\end{tabular}

are summarized in Table 2. For niobic acid sample, NBA prepared by hydrolysis of niobium pentoxide, no diffraction lines can be observed on the XRD pattern, suggesting that the niobic acid phase is fully amorphous. On the other hand, niobium oxide sample, NBO prepared by calcination of ammonium niobium oxalate at $550^{\circ} \mathrm{C}$ shows splitting of the diffraction line at around $2 \theta=29^{\circ}$, indicating that the sample is crystalline niobium oxide phase $\left(\mathbf{T}-\mathrm{Nb}_{2} \mathrm{O}_{3}\right)$ with orthorhombic structure [20]. Similar orthorhombic phase of niobium oxide has been prepared by Paulis et al. [21] for the preparation of niobium oxide from a precursor solution of niobium chloride in ethanol, and calcined at $700^{\circ} \mathrm{C}$. The XRD patterns of samples $X \mathrm{Nb} / \mathrm{TS}-1$ reveal that the samples contain framework structures of the MFI type zeolite. The observations of samples $X \mathrm{Nb} / \mathrm{TS}-1$ show that the structure of TS-1 is not strongly affected by the presence of impregnated niobium. No diffraction line assigned for crystalline phase of the niobium oxide is present in the XRD pattern. The result indicated that niobium was well dispersed over TS-1. This also suggested that the niobium species was present in the form of amorphous niobium oxide hydrate, since it was prepared by hydrolysis of niobium ethoxide and was not calcined at temperature higher than $400^{\circ} \mathrm{C}$. In addition, the peak intensity of TS-1 is drastically decreased to $60 \%$ after impregnation of $3.4 \mathrm{wt} \%$ of niobium on the TS-1 (sample $3 \mathrm{Nb} / \mathrm{TS}-1$ ). Moreover, its intensity decreased significantly as niobium loading increased. It is suggested that niobium could be located on the surface of TS-1 or covering the surface of TS-1. Since the size of niobium precursor, that is, $\mathrm{Nb}(\mathrm{OEt})_{5}$ is $c a .1 .1 \mathrm{~nm}$ is larger than the pore-entrance size of TS-1 (ca. $0.55 \mathrm{~nm})$, hence, the niobium species most probably be attached to the external surface of TS-1 [18].

The infrared spectra of the samples in the lattice vibration region between 1400 and $400 \mathrm{~cm}^{-1}$ are depicted in Figure 2. Niobic acid (sample NBA) shows a major



FIgURE 1: XRD pattern of the NBA, NBO, TS-1, and $X \mathrm{Nb} / \mathrm{TS}-1$ samples.

strong band centered at $586 \mathrm{~cm}^{-1}$ and a shoulder band at $933 \mathrm{~cm}^{-1}$. This spectrum is consistent with the skeletal vibration previously reported for amorphous niobic acid $[12,21,22]$. The spectrum of niobium oxide crystals (sample NBO) exhibits two strong bands at 615 and $850 \mathrm{~cm}^{-1}$. The broad band at a higher frequency ca. $>850 \mathrm{~cm}^{-1}$ is associated with the stretching mode of $\mathrm{Nb}=\mathrm{O}$ bonds (niobyl species) in a highly distorted $\mathrm{NbO}_{6}$ groups, while the band around 




FIgURE 2: FTIR spectra of the NBA, NBO, TS-1, and XNb/TS-1 samples.

$600 \mathrm{~cm}^{-1}$ can be assigned to the stretching of longer bridging $\mathrm{Nb}-\mathrm{O}-\mathrm{Nb}$ bonds [22]. For the infrared spectra of samples $X \mathrm{Nb} / \mathrm{TS}-1$, a small band at around $970 \mathrm{~cm}^{-1}$ characteristic for titanium ions in the tetrahedral structure is still present after impregnation of niobium. No additional band after impregnation of niobium into the TS- 1 can be observed. This finding shows that impregnation of niobium has not affected the MFI structure of TS-1 significantly. Infrared spectroscopy technique was not able to detect the presence of niobic acid in the samples $X \mathrm{Nb}$ /TS-1, due to the low vibration intensity of pure niobic acid itself as compared to sample TS- 1 .

The UV-vis DR spectra of the samples NBA, NBO, TS1 , and $\mathrm{Nb} / \mathrm{TS}-1$ are shown in Figure 3. The UV-vis spectrum of NBO sample exhibits a maximum band at around $295 \mathrm{~nm}$ and a shoulder band at around $243 \mathrm{~nm}$, while sample NBA shows a sharp band at around $280 \mathrm{~nm}$ and a shoulder band at around $240 \mathrm{~nm}$. These bands are characteristic for distorted octahedral and tetrahedral species, respectively, [22, 23]. These bands are attributed to the charge transfer transitions $\mathrm{O}^{2-}$ to $\mathrm{Nb}^{5+}$, which can be associated to the energy gap between the $\mathrm{O} 2 \mathrm{p}$-valence band and the $\mathrm{Nb} 4 \mathrm{~d}$-conductance band [22]. In the supported niobium oxide, the position and width of the UV absorption bands of niobium oxide species were observed to depend on the niobium content and the size of niobia crystallites. The decrease in niobium concentration leads to a blue shift of the charge transfer band, caused by decreasing of the size of niobium oxide species. With decreasing of niobium loading, the LMCT peak maximum shifts from a higher to a lower wavelength. Gao et al. [11] found that in the niobium oxide compounds containing polymerized $\mathrm{NbO}_{6}$ structures with five or six $\mathrm{Nb}-$ $\mathrm{O}-\mathrm{Nb}$ bonds around the central $\mathrm{Nb}$ atom, the decrease of the layer thickness of the layered niobium oxide compounds slightly increases the edge energy. Sample TS-1 shows a single strong band at $215 \mathrm{~nm}$ characteristic for tetrahedral titanium framework. Impregnation of niobium on the TS-1 (sample $3 \mathrm{Nb} / \mathrm{TS}-1$ ) shows a strong band at around $240 \mathrm{~nm}$ assigned to octahedral niobium species. The intensity of this band in the samples $X \mathrm{Nb} / \mathrm{TS}-1$ increased as the niobium content in the samples increased. Meanwhile, the band characteristic for tetrahedral titanium at about $215 \mathrm{~nm}$ cannot be observed due to the overlapping of this band with the band of niobium oxide that has much higher intensity. In addition, this charged transfer band shifted to the higher wavelength as the niobium loading increased. The samples $10 \mathrm{Nb} / \mathrm{TS}-1$ and $20 \mathrm{Nb} / \mathrm{TS}-1$ showed a shoulder band at around $245 \mathrm{~nm}$ and an intense band at around $280 \mathrm{~nm}$, in which sample $10 \mathrm{Nb} / \mathrm{TS}-1$ has lower intensity bands than that of sample $20 \mathrm{Nb} / \mathrm{TS}-1$. These bands were also observed on bulk niobic acid (sample NBA), suggesting the presence of similar species in this sample. The shift of the UV-vis band position as the metal oxide content increases is generally attributed to the enhancement of degree of polymerization. Therefore, in this study, the increase of niobium content has led to an increase in the degree of polymerization of the niobium species. According to Tanaka et al. [24], $\mathrm{Nb}_{2} \mathrm{O}_{5} / \mathrm{Al}_{2} \mathrm{O}_{3}$ with low niobium loading could be represented by monomer or dimmer species, whereas at high niobium loading, the samples could be identified by the presence of $\mathrm{Nb}_{2} \mathrm{O}_{5}$ particles.

Figure 4 shows the TPR profiles of the samples. The TPR profile of sample NBO: crystalline niobium oxide displays a low signal and two high signals of hydrogen consumption centered at around $680^{\circ} \mathrm{C}, 870^{\circ} \mathrm{C}$, and higher than $1000^{\circ} \mathrm{C}$ (not complete). Sample NBA prepared by hydrolysis of niobium ethoxide and calcined at $200^{\circ} \mathrm{C}$, exhibited three regions of hydrogen consumption, that is, a negative peak at around $550^{\circ} \mathrm{C}$ and the high positive peaks at around $900^{\circ} \mathrm{C}$ and at a higher temperature above $1000^{\circ} \mathrm{C}$. The negative peak can be attributed to $\mathrm{CO}$ or $\mathrm{CO}_{2}$ formation due to carbon residue from the niobium ethoxide that was not fully hydrolyzed. The first positive peak was attributed to the reduction of $\mathrm{Nb}^{5+}$ to $\mathrm{Nb}^{4+}$ in the form of $\mathrm{Nb}_{2} \mathrm{O}_{5}$ to $\mathrm{NbO}_{2}$ [1], while for reduction of $\mathrm{NbO}_{2}$ to lower oxidation state of niobium, $\mathrm{NbO}$ needed higher reduction temperature. The TPR profile of sample $20 \mathrm{Nb} / \mathrm{TS}-1$ shows a major peak at around $925^{\circ} \mathrm{C}$, which is also observed on amorphous bulk $\mathrm{Nb}_{2} \mathrm{O}_{5}$, suggesting the presence of similar species of niobium on both samples. The reduction temperature of sample $20 \mathrm{Nb} / \mathrm{TS}-1$ is slightly higher than that of sample $\mathrm{NBA}$, indicating that the interaction between niobic acid 




FIgURE 3: UV-Vis DR spectra of the NBA, NBO, TS-1, and XNb/TS1 samples.

and the surface of TS-1 exists. On the contrary, samples $3 \mathrm{Nb} / \mathrm{TS}-1$ and $10 \mathrm{Nb} / \mathrm{TS}-1$ do not show any significant peak in the reduction temperature range, although the sample contains niobium. This finding is explained to be due to several factors. Low amount of niobium loading results in high dispersion of niobium on the surface of TS-1 that promotes interaction between niobium and TS-1. Pereira et al. [25] found that high dispersions promote intimate contact between niobium and the silica surface, $\mathrm{Nb}-\mathrm{O}-\mathrm{Si}$ bonding in relation to $\mathrm{Nb}-\mathrm{O}-\mathrm{Nb}$ bonding prevailing. The formation of a surface of niobia monolayer is derived from the $\mathrm{Nb}-\mathrm{O}-\mathrm{Si}$ bonding [26]. It also can be explained based on the electronegativity concept that the presence of silicon in the coordination sphere of niobium should increase the electronic density niobium. Thus, the reduction of niobium from $\mathrm{Nb}^{+5}$ to $\mathrm{Nb}^{+4}$ was more difficult to occur [25]. Recently, Mendez et al. [27] found that $20 \mathrm{wt} \%$ of niobium supported on $\mathrm{Al}_{2} \mathrm{O}_{3}$ did not show any hydrogen uptake as an indication of the strong interaction of niobium with $\mathrm{Al}_{2} \mathrm{O}_{3}$.

The hydroxyl groups and acidity of the samples were monitored by infrared spectroscopy technique. The wafer sample was put in the glass cell and evacuated at $200^{\circ} \mathrm{C}$ for 16 hours under vacuum. The infrared spectra were recorded at room temperature. Figure 5 shows the infrared spectra of the samples TS-1, NBA, NBO, XNb/TS-1, and a mechanical mixture of NBA and TS-1 (sample MM-20NBA+TS-1, $20 \mathrm{wt} \%$ of NBA) after evacuation at $200^{\circ} \mathrm{C}$. TS- 1 shows a sharp peak at around $3743 \mathrm{~cm}^{-1}$ characteristic of hydroxyl silanol groups. Niobic acid (sample NBA) shows a small peak at around $3700 \mathrm{~cm}^{-1}$ and a broad peak centered at around $3400 \mathrm{~cm}^{-1}$ that can be assigned to hydroxyl stretching mode of free $\mathrm{Nb}-\mathrm{O}-\mathrm{H}$ groups and hydroxyl with hydrogen bonding, respectively, $[22,28]$. On the other hand, crystalline niobium oxide does not show any peak in the vibration

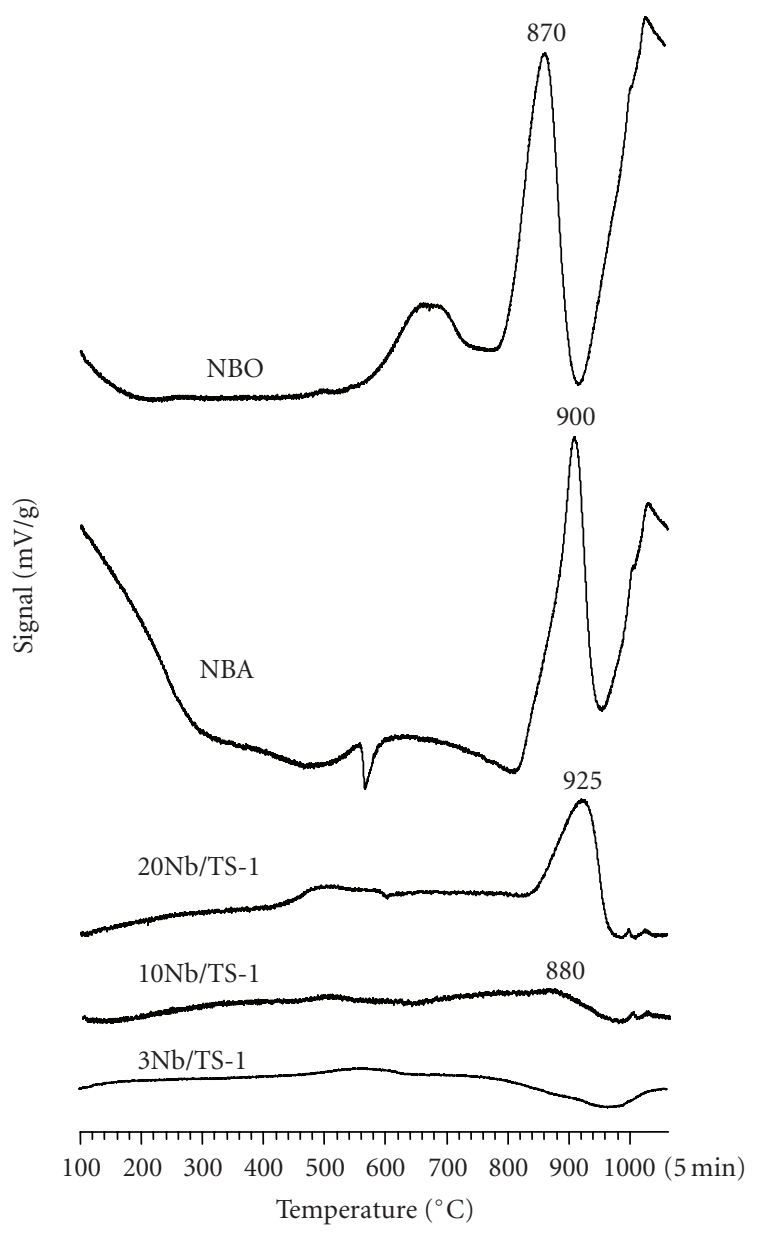

FIgURE 4: TPR profiles of the NBA, NBO, and $X \mathrm{Nb}$ /TS-1 samples.

region of hydroxyl groups indicating that crystalline niobium oxide does not contain any hydroxyl groups. A different finding was reported recently by Braga et al. [12] for niobium oxide calcined at $800^{\circ} \mathrm{C}$. They observed the peaks at around $3748 \mathrm{~cm}^{-1}$ and $3526 \mathrm{~cm}^{-1}$ assigned to terminal hydroxyl bonded to a slightly distorted $\mathrm{NbO}_{6}$ and hydroxyl with hydrogen bonding, respectively. The peak at around $3743 \mathrm{~cm}^{-1}$ disappeared as niobium was loaded on the TS-1. A small peak at around $3733 \mathrm{~cm}^{-1}$ and a broad peak centered at around $3530 \mathrm{~cm}^{-1}$ were observed in samples $X \mathrm{Nb} / \mathrm{TS}-1$. In addition, a peak at around $3733 \mathrm{~cm}^{-1}$ of sample $20 \mathrm{Nb} / \mathrm{TS}$ 1 has higher intensity as compared to samples $3 \mathrm{Nb} / \mathrm{TS}-1$ and $10 \mathrm{Nb} / \mathrm{TS}-1$. Meanwhile, a mechanical mixture of $20 \mathrm{wt} \%$ NBA in TS-1 only shows a peak similar to that of TS-1 at around $3744 \mathrm{~cm}^{-1}$ assigned for silanol hydroxyl groups. Although this mixture contains $20 \mathrm{wt} \%$ of NBA, however, no peak at around $3700 \mathrm{~cm}^{-1}$ assigned for $\mathrm{Nb}-\mathrm{O}-\mathrm{H}$ can be observed. It suggests that the amount of hydroxyl groups of $\mathrm{Nb}-\mathrm{OH}$ in the sample NBA is much lower than the amount of silanol groups of TS-1. For samples $X \mathrm{Nb} / \mathrm{TS}-1$, a drastic decrease of silanol species present on the surface of TS-1 indicates that there is strong interaction between niobium and TS-1 (niobium bonded with -O-Si, replacing hydrogen atom of silanol species in the TS-1). Since niobic acid does 


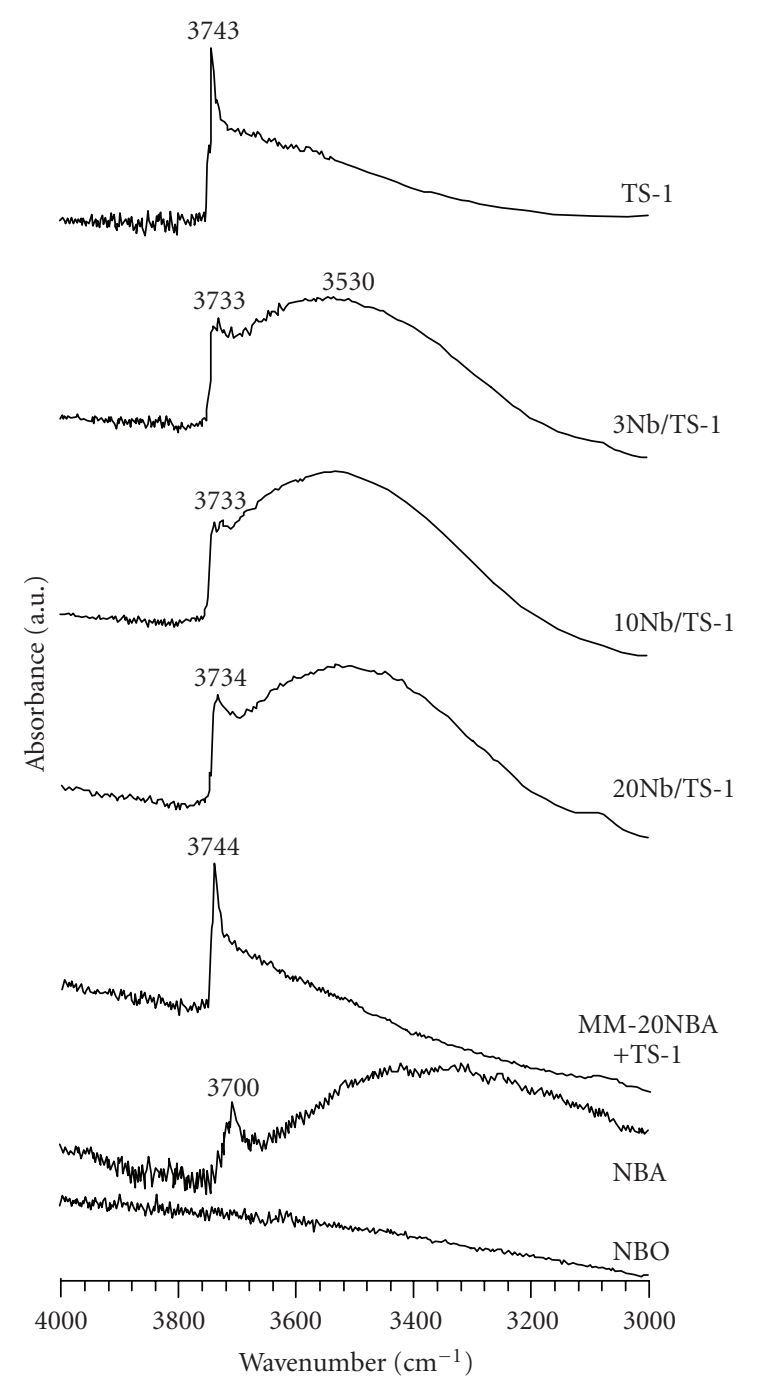

FIGURE 5: FTIR spectra of the NBA, NBO, TS-1, and $X \mathrm{Nb} / \mathrm{TS}-1$ samples in the hydroxyl vibration region, after evacuation under vacuum at $200^{\circ} \mathrm{C}$.

not show any peak in this region, the results clearly suggests that the niobium species has covered the surface of TS-1. Therefore, depositions of niobium oxide species on TS-1 consume the surface $\mathrm{Si}-\mathrm{OH}$ groups of TS-1. Consequently, the amount silanol groups decreased.

The effect of evacuation temperature on the hydroxyl groups present in the sample was studied for sample $3 \mathrm{Nb} / \mathrm{TS}$ 1 at evacuation temperatures 120, 200, and $400^{\circ} \mathrm{C}$ (Figure 6). The spectrum of sample $3 \mathrm{Nb} / \mathrm{TS}-1$ after evacuation at $120^{\circ} \mathrm{C}$ for 24 hours shows a small peak at around $3735 \mathrm{~cm}^{-1}$ and a broad peak with high intensity center at around $3500 \mathrm{~cm}^{-1}$ characteristic for hydroxyl groups of silanol and hydrogen bonding, respectively. After evacuation at $200^{\circ} \mathrm{C}$ for 24 hours, the peaks for silanol groups are still maintained, but the peak for hydrogen bonding is shifted to a higher frequency at around $3530 \mathrm{~cm}^{-1}$ with lower intensity. Continuing evacuation at $400^{\circ} \mathrm{C}$ for an hour, results in slightly higher intensity of silanol but still at

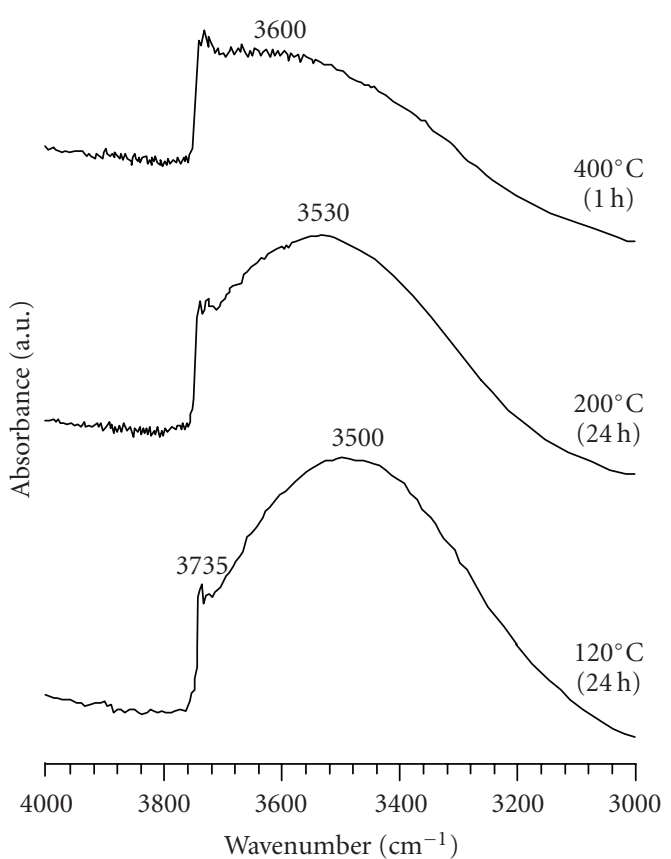

FIGURE 6: FTIR spectra of the sample $3 \mathrm{Nb} / \mathrm{TS}-1$ in the hydroxyls region after evacuation under vacuum at temperature 120, 200, and $400^{\circ} \mathrm{C}$.

similar frequency, while the hydroxyl of hydrogen bonding becomes a shoulder peak and shifted to the higher frequency at around $3600 \mathrm{~cm}^{-1}$. The decreasing of hydroxyl groups of hydrogen bonding and increasing of silanol groups indicates that the hydroxyl groups of hydrogen bonding have interacted with the silanol groups. Therefore, as evacuation temperature increased, the hydroxyl groups of hydrogen bonding decreased, consequently, the silanol increased.

The type and amount of acid sites in the sample were monitored and measured by pyridine adsorption. Pyridine was adsorbed at room temperature after evacuation of sample at $200^{\circ} \mathrm{C}$ for 16 hours in vacuum. The infrared spectra were collected after evacuation of pyridine at $150^{\circ} \mathrm{C}$ for an hour. Figure 7 shows the infrared spectra of the samples in the pyridine region. Sample NBO does not show any peak which indicates that crystalline niobium oxide has no acidity. Sample NBA shows the peaks at 1636, 1609, $1575,1540,1489$, and $1448 \mathrm{~cm}^{-1}$. The peaks at around 1540 and $1448 \mathrm{~cm}^{-1}$ are due to Brønsted and Lewis acid sites, respectively. Similar findings have been reported by Morais et al. [29] and da Silva et al. [30] for niobic acid. It has been reported also that the acidity of niobic acid also depends on the calcination temperature [31]. The number of Lewis acid sites increased with increasing pretreatment temperatures up to $500^{\circ} \mathrm{C}$ and then decreased at higher temperatures. On the other hand, Brønsted acid sites decreased with increasing temperature above $100^{\circ} \mathrm{C}$. As the number of coordinated water molecules increased, the number of Brønsted acid sites decreased, the concentration of hydronium ions $\left(\mathrm{H}_{3} \mathrm{O}^{+}\right)$ increased, and the formation of $\mathrm{H}_{2} \mathrm{O}-\mathrm{HO}$ species is observed [32]. 


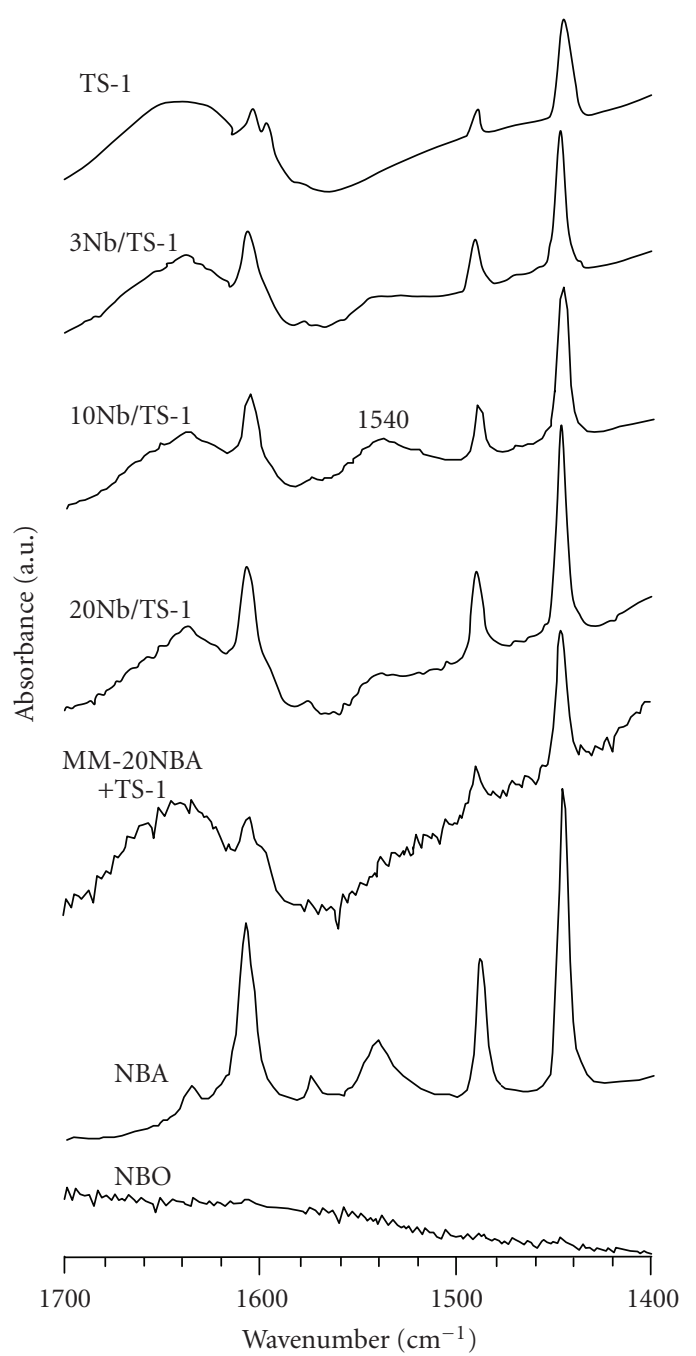

FIGURE 7: FTIR spectra of the NBA, NBO, TS-1, and $X \mathrm{Nb} / \mathrm{TS}-1$ samples after evacuation at $200^{\circ} \mathrm{C}$ for 24 hours followed by pyridine adsorption at room temperature and evacuation at $150^{\circ} \mathrm{C}$ for one hour, in the pyridine regions.

Niobium oxide samples containing TS-1 showed the peaks similar to that of sample NBA. However, the intensity of the characteristic peaks for Brønsted and Lewis acid sites at around 1540 and $1448 \mathrm{~cm}^{-1}$, respectively, was lower than that of sample NBA. Jehng and Wachs [13] and Shirai et al. [15] have reported the evidence of the presence of both Brønsted and Lewis acid sites in niobium oxide supported on the silica, while Mendes et al. [27] only found Lewis acid sites in silica supported niobic acid. In this study, a mechanical mixture of niobic acid and TS-1 (sample MM-20NBA+TS-1) only shows the peaks at around 1608,1489 , and $1447 \mathrm{~cm}^{-1}$, which are similar to those of sample TS-1. This finding indicates that the sample NBA in sample MM-20NBA+TS- 1 contained low amount of acid sites.

The infrared spectra shown in Figure 7 confirm that all samples $X \mathrm{Nb} / \mathrm{TS}-1$ have Brønsted and Lewis acid sites. The amount of Brønsted and Lewis acid sites calculated on the basis of the peak at around 1540 and $1448 \mathrm{~cm}^{-1}$ are tabulated

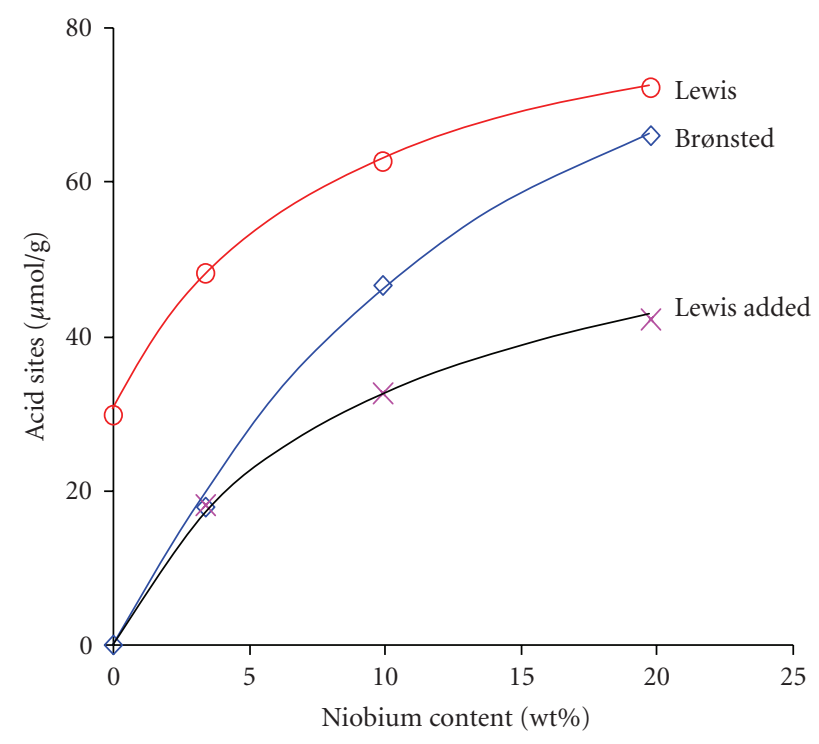

FIGURE 8: Correlation between the niobium content and the amount of acid sites of the catalysts.

in Table 3. It showed that the amount of Brønsted and Lewis acids increases with the increasing niobium loading on the support. The area under the peak at around $1490 \mathrm{~cm}^{-1}$ characteristic for the mixture of Brønsted and Lewis acids also increased as the niobium loading increased. This finding indicates that niobium plays a role in the formation of both Brønsted and Lewis acid sites. Similar findings have been reported by Jehng and Wachs [13] and Shirai et al. [15] for niobium oxide supported on silica.

Figure 8 shows the correlation between niobium content (wt $\%$ ) in the solid samples and the amount of the Brønsted and Lewis acid sites. It shows that addition of niobium onto TS-1 up to $10 \mathrm{wt} \%$ results in the increase amount of Brønsted acid sites. Although the amount of Brønsted acid sites keep on increasing with further increased in niobium loading up to $20 \mathrm{wt} \%$, the additional amount of Brønsted acid produced is slightly lower compared to that of the first addition (sample $10 \mathrm{Nb} / \mathrm{TS}-1$ ). This finding suggests that not all of the added niobium creates Brønsted acid sites. Based on this observation, it is suggested that the Brønsted acid sites may be present only on the surface of niobic acid. Similar pattern is observed also for the formation of Lewis acid sites.

According to Jehng and Wachs [13, 14], interaction between $\mathrm{Nb}_{2} \mathrm{O}_{5}$ and acidic surfaces $\left(\mathrm{SiO}_{2}\right.$ and $\mathrm{Al}_{2} \mathrm{O}_{3}$ ) resulted in the formation of slightly distorted $\mathrm{NbO}_{6}, \mathrm{NbO}_{7}$, and $\mathrm{NbO}_{8}$ sites. The slightly distorted $\mathrm{NbO}_{6}, \mathrm{NbO}_{7}$, and $\mathrm{NbO}_{8}$ groups only possess $\mathrm{Nb}-\mathrm{O}$ bonds and are associated with Brønsted acid sites. The highly distorted $\mathrm{NbO}_{6}$ octahedral possesses $\mathrm{Nb}=\mathrm{O}$ bonds in which associated with Lewis acid sites. In this study, it is found that the increased amount of Lewis acid sites present in the sample with low amount of niobium loading (3Nb/TS-1) is similar with the increased amount of Brønsted acid sites. This suggests that the amount of slightly distorted $\mathrm{NbO}_{6}, \mathrm{NbO}_{7}$, and $\mathrm{NbO}_{8}$ groups is similar with those of highly distorted NbO6. 
TABLE 3: The amount of the Brønsted and Lewis acid sites and the area under the peak at around $1490 \mathrm{~cm}^{-1}$ of the samples.

\begin{tabular}{lcccc}
\hline Sample & Brønsted, $\mu \mathrm{mol} / \mathrm{g}$ & Lewis, $\mu \mathrm{mol} / \mathrm{g}$ & Lewis added, $\mu \mathrm{mol} / \mathrm{g}^{(\#)}$ & Peak area at $1490, \mathrm{~cm}^{-2(*)}$ \\
\hline TS-1 (1\%) & 0 & 30 & - & 0.14 \\
$3 \mathrm{Nb} / \mathrm{TS}-1$ & 18 & 48 & 33 & 0.46 \\
$10 \mathrm{Nb} / \mathrm{TS}-1$ & 47 & 63 & 42 & 0.52 \\
$20 \mathrm{Nb} / \mathrm{TS}-1$ & 66 & 72 & - & 0.93 \\
$\mathrm{NBO}$ & 0 & 0 & - & 0 \\
$\mathrm{NBA}$ & 101 & 145 & 1.75 \\
\hline
\end{tabular}

${ }^{(\#)}$ Additional amount of the Lewis in the samples Nb/TS-1, calculated by deduction of Lewis acid in the samples Nb/TS-1 by sample TS-1.

${ }^{*}$ Area of the peak at around $1490 \mathrm{~cm}^{-1}$, characteristic for the mixture of Brønsted and Lewis acid sites.

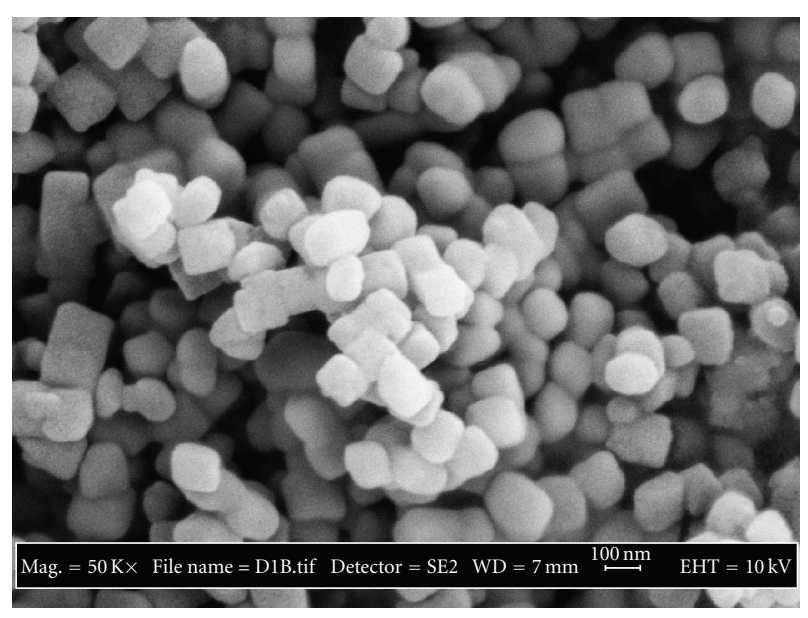

(a)

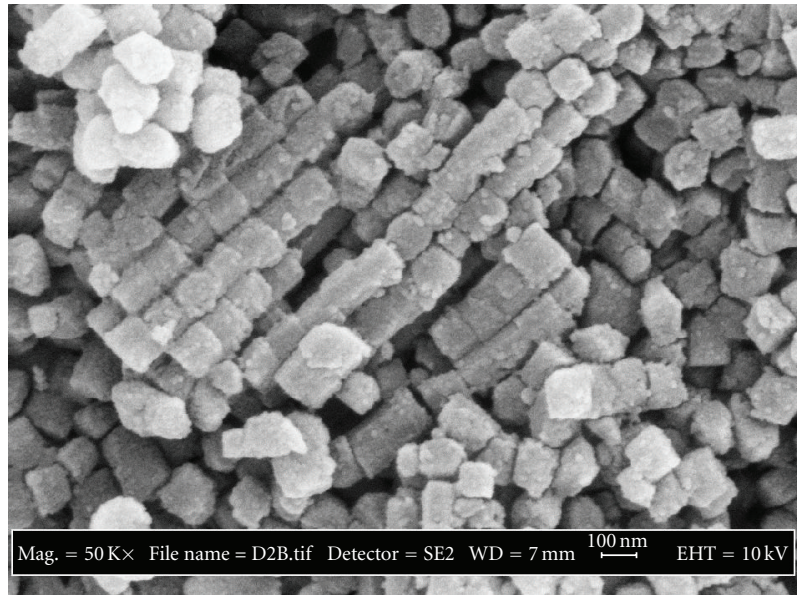

(b)

FIgURE 9: The FESEM images of the materials (a) TS-1 and (b) $10 \mathrm{Nb} / \mathrm{TS}-1$.

However, at higher niobium loading, it is found that the increased amount of Lewis acid is slightly lower than that of Brønsted acid. It indicates that at higher niobium loading, the presence of slightly distorted $\mathrm{NbO}_{6}, \mathrm{NbO}_{7}$, and $\mathrm{NbO}_{8}$ groups is more prominent. This finding was supported by the results obtained from the TPR and infrared of hydroxyl groups data, which indicate the interaction between niobium species with the support TS-1 (Nb-O-Si). Since Nb is more electronegative compared to $\mathrm{Si}$ or $\mathrm{Ti}$ (Pauling value of $\mathrm{Nb}, \mathrm{Si}$, and $\mathrm{Ti}$ are 1.6, 1.0, and 1.5, resp.) means that niobia oxide shows more ionic character. Therefore, generation of Lewis acid sites in the samples $X \mathrm{Nb} / \mathrm{TS}-1$ can be a consequence of the higher ionicity of the $\mathrm{Nb}-\mathrm{O}$ bond. This suggests that higher Lewis acid could be generated in the first layer of the supported niobium oxide on TS-1.

Further explanation is demonstrated by pyridine adsorption, which shows that Nb-loaded TS-1 has Brønsted acid sites. On the other side, sample physical mixing of niobic acid and TS-1 (20 wt\% NBA) only shows Lewis acid sites. In this sample, there is no chemical interaction between $\mathrm{Nb}-$ $\mathrm{O}-\mathrm{Si}$. The acid sites in this sample are purely come from sample NBA with a small amount of acid sites. Meanwhile, in the $\mathrm{Nb} / \mathrm{TS}-1$ sample, the interaction between $\mathrm{Nb}-\mathrm{O}-\mathrm{Si}$ occurs. Therefore, generation of Brønsted acid sites can be expected since protons are required to balance the excess negative charges on the oxygen atoms, analog of $\mathrm{Al}$ atom in the aluminosilicate molecularsieves. Generation of Brønsted acid sites is also in accordance with Kung's assumptions $[33,34]$. They explained two models, that is, (1) an electronic interaction exists between $\mathrm{Nb}_{2} \mathrm{O}_{5}$ and TS-1 components, and (2) $\mathrm{Nb}-\mathrm{O}$ bonds neighboring the more covalent $\mathrm{Si}-\mathrm{O}$ possess a higher ionicity. It means that the electron density of the $\mathrm{OH}$ bonds is reduced by the inductive effect of the nearby electronegative anions. As a consequence, this weakens the $\mathrm{OH}$ bond and generates the Brønsted acid sites. Furthermore, based on the XPS data by Noronha et al. [35] and Bosman et al. [36] found the increased in the covalency of $\mathrm{Si}-\mathrm{O}$ bonds in binary $\mathrm{SiO}_{2}-\mathrm{TiO}_{2}$ and $\mathrm{SiO}_{2}-\mathrm{ZrO}_{2}$ systems, respectively, that leads to the creation of Brønsted acid sites.

Samples morphology were monitored using field emission scanning electron microscope. Figure 9 shows the FESEM images of samples TS- 1 and $10 \mathrm{Nb} / \mathrm{TS}-1$ material. The FESEM image shows that TS-1 has cubic morphology with the crystal size around $100 \mathrm{~nm}$. Meanwhile, a grubby TS- 1 crystal is observed in the sample $10 \mathrm{Nb} / \mathrm{TS}-1$ with the crystal size similar to that of TS-1 sample, that is, around $100 \mathrm{~nm}$. Based on the UV-vis DR finding, this sample contained niobic acid. Therefore, it is concluded that a small particle observed on the surface of TS- 1 is niobic acid. However, the morphology of TS-1 is not affected by impregnation of niobic acid. 
3.2. Performance of Catalysts. The catalytic activities of the TS-1, niobium compounds, and niobium-containing TS-1 samples were tested in the epoxidation of 1 -octene with aqueous $\mathrm{H}_{2} \mathrm{O}_{2}$ as oxidant in acetone at $70^{\circ} \mathrm{C}$. Table 4 shows the catalytic results of the samples. For the conversion of 1octene after 48 hours of reaction time (Table 4 ), only below $0.2 \mathrm{mmol}$ of 1 -octene has converted using samples $\mathrm{NBO}$ and NBA. This conversion is much lower as compared to the 1octene conversion catalyzed by samples TS- 1 and Nb/TS- 1 , that is, up to $1.6 \mathrm{mmol} 1$-octene. Meanwhile, it is found that the catalytic activity of samples TS- 1 and Nb/TS- 1 in term of conversion of 1-octene are not much different. This finding suggests that the niobium content is not taken into account of the 1-octene conversion. The low conversion of 1-octene on the samples NBO and NBA supported this implication.

Figure 10 shows the graph of the formation of the 1,2epoxyoctane versus reaction time using various samples as catalysts. Generally, both amorphous and crystalline form of niobium oxides (samples NBA and NBO) show no observable activity toward the formation of 1,2-epoxyoctane, that is, 0.04 and $0.01 \mathrm{mmol}$, respectively, after 48 hours of reaction time. These findings indicate that both niobium oxides are not active as catalysts for epoxidation of 1octene at $70^{\circ} \mathrm{C}$. However, some researchers have reported the capability of niobium oxide for oxidation reactions at high temperature $\left(>200^{\circ} \mathrm{C}\right)$ using oxygen as oxidant. Examples are methanol oxidation that can be performed by catalyst $\mathrm{Nb}_{2} \mathrm{O}_{5} / \mathrm{SiO}_{2}$ at temperature as low as $230^{\circ} \mathrm{C}[11,37]$ and alkane oxidation at high temperature, $550^{\circ} \mathrm{C}$ [38]. Wachs et al. [39] and Védrine et al. [40] have also reported the redox properties of niobium oxide. Meanwhile, Gallo et al. [23] have reported that the oxidation activity of niobiumcontaining MCM-41 (Nb-MCM-41) in the epoxidation of alkene at higher temperature. Nb-MCM-41 also was applied in the oxidation of butyl sulfide and cyclohexene using $\mathrm{H}_{2} \mathrm{O}_{2}$ at low temperature [41-44]. In that case, niobium species is located in the framework of molecularsieves. Therefore, in this study, it is suggested that supported niobium oxide become an active catalyst for oxidation reaction at high temperature.

The graph of the formation of 1,2-epoxyoctane from the epoxidation of 1-octene catalyzed by samples TS- 1 and $X \mathrm{Nb} / \mathrm{TS}-1$ are shown in Figure 10. All niobium containing TS-1 show the higher rate of the formation of 1,2epoxyoctane up to 6 hours of the reaction times as compared to TS-1. Sample $3 \mathrm{Nb} / \mathrm{TS}-1$ shows the highest rate of the formation of 1,2-epoxyoctane, followed by sample $10 \mathrm{Nb} / \mathrm{TS}$ 1 that shows similar rate of the formation of 1,2-epoxyoctane in the first reaction time with sample $20 \mathrm{Nb} / \mathrm{TS}-1$, and the lowest rate is observed in sample TS-1. However, at the reaction time longer than 6 hours, the rates of the formation of 1,2-epoxyoctane of samples niobium containing TS-1 are lower than that of sample TS-1. It is clearly seen that TS- 1 is still active at reaction time longer than 24 hours.

The enhancement of the rate of the formation of 1,2epoxyoctane in the initial reaction time can be explained on the basis of the relationship between the hydrophilic properties of the catalysts and the formation of the active oxo-titanium intermediate. The infrared spectra of samples

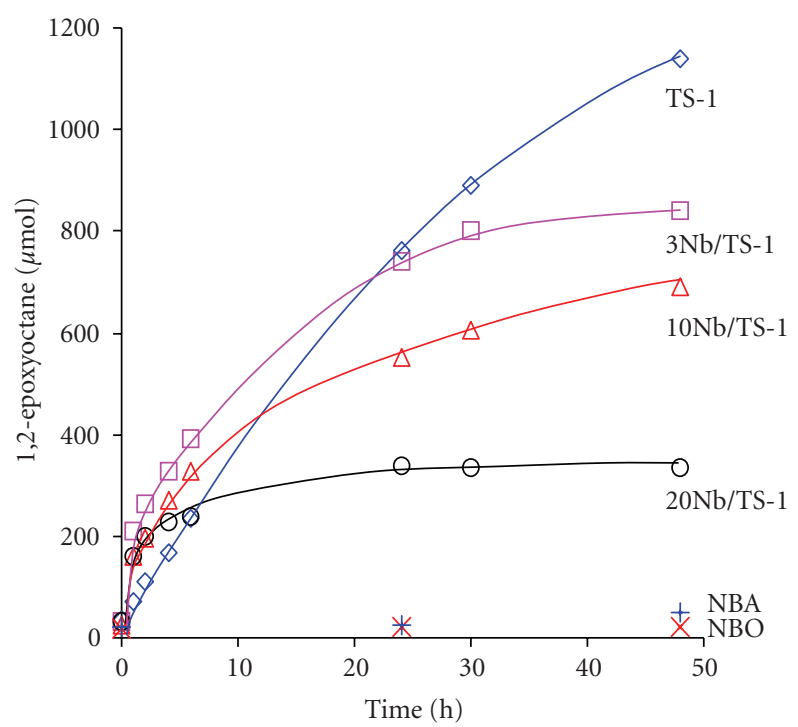

FIgURE 10: The formation of 1,2-epoxyoctane from 1-octene epoxidation using $\mathrm{H}_{2} \mathrm{O}_{2}$ at $70^{\circ} \mathrm{C}$ catalyzed by NBA, NBO, TS- 1 , and $\mathrm{XNb} / \mathrm{TS}-1$.

$X \mathrm{Nb} / \mathrm{TS}-1$ show the characteristic of hydroxyl groups of hydrogen bonding at around $3500 \mathrm{~cm}^{-1}$ that does not observe in sample TS- 1 . This indicates that samples Nb/TS-1 have higher hydrophilic properties as compared with sample TS-1. This finding is further suggested that the capability of samples $X \mathrm{Nb} / \mathrm{TS}-1$ to adsorb $\mathrm{H}_{2} \mathrm{O}_{2}$ solution in water is higher than that of sample TS- 1 , since $\mathrm{H}_{2} \mathrm{O}_{2}$ is hydrophilic. It has been reported that the active species in the epoxidation reaction using hydrogen peroxide as oxidant was oxotitanium species $[45,46]$. Therefore, it was expected faster formation of the oxo-titanium species in the catalyst containing hydrophilic character. Consequently, the production of 1,2-epoxyoctane is remarkable faster in samples $\mathrm{XNb} / \mathrm{TS}$ 1. Meanwhile, decreasing of the 1,2-epoxyoctane yield in the longer reaction time is mainly due to 1,2-epoxyoctane has converted into 1,2-octanediol. The formation of 1,2octanediol versus reaction time using TS- 1 and $X \mathrm{Nb} / \mathrm{TS}-1$ as catalysts is shown in Figure 11. Samples NBO and NBA showed no noticeable activity toward the formation of 1,2epoxyoctane as shown in Figure 10. Consequently, there was no 1,2-octanediol that can be observed from these reactions. Meanwhile, samples TS- 1 and Nb/TS- 1 show their activity toward the formation of 1,2-octanediol. However, samples $\mathrm{Nb} / \mathrm{TS}-1$ gave higher yield of 1,2-octanediol compare to TS-1. In addition, the yield of 1,2-octanediol increased as the amount of niobium increased. This may be due to the increase of the amount of Brønsted acid present in the catalysts as demonstrated by pyridine adsorption study. However, the selectivity of the diols seems to be lower since TS- 1 alone show considerable acidity, for example, it catalyzes oxidative cyclization [47].

Moreover, the starting time of the formation of 1,2octanediol is different among the catalysts. The highest of starting time is observed on sample $20 \mathrm{Nb} / \mathrm{TS}-1$, followed by sample $10 \mathrm{Nb} / \mathrm{TS}-1$ and $3 \mathrm{Nb} / \mathrm{TS}-1$, and the last is TS- 1 , that 
TABLE 4: Catalytic activity of the $X \mathrm{Nb} / \mathrm{TS}-1$ in the epoxidation of 1-octene with $\mathrm{H}_{2} \mathrm{O}_{2}$ at $70^{\circ} \mathrm{C}$ for $48 \mathrm{~h}$.

\begin{tabular}{|c|c|c|c|c|c|}
\hline Catalyst & Conversion, $\%{ }^{(\#)}$ & Brønsted, $\mu \mathrm{mol}$ & Diol, $\mu \mathrm{mol}$ & TOF, $10^{-1} \mathrm{~h}^{-1(*)}$ & Selectivity, $\%^{(\ddagger)}$ \\
\hline NBO & 0.25 & - & - & - & - \\
\hline NBA & 0.19 & - & - & - & - \\
\hline TS-1 & 1.63 & 0 & 20 & - & 1.21 \\
\hline $3 \mathrm{Nb} / \mathrm{TS}-1$ & 1.53 & 1.0 & 73 & 32 & 4.75 \\
\hline $10 \mathrm{Nb} / \mathrm{TS}-1$ & 1.81 & 2.8 & 105 & 15 & 5.82 \\
\hline $20 \mathrm{Nb} / \mathrm{TS}-1$ & 1.68 & 4.6 & 133 & 13 & 7.93 \\
\hline
\end{tabular}

${ }^{(\#)} \mathrm{mmol}$ of 1 -octene reacted.

(‡) $\mathrm{mmol}$ of 1,2-octanediol per mmol of 1 -octene reacted, in $\%$.

${ }^{(*)}$ TOF is calculated on the basis of the total Brønsted acid in the catalysts for the production of 1,2-octanediol.

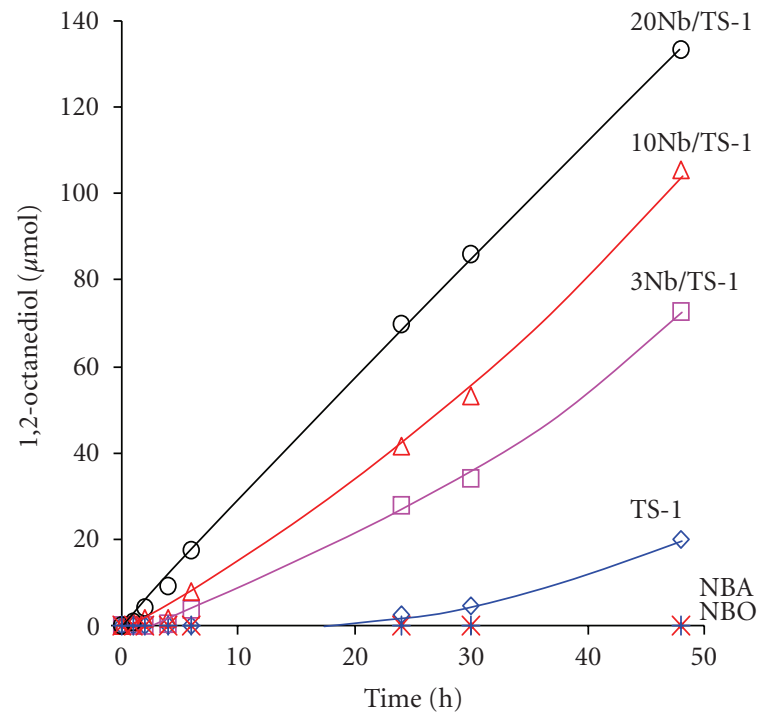

FIGURE 11: The yield of 1,2-octanediol from 1-octene epoxidation of using $\mathrm{H}_{2} \mathrm{O}_{2}$ at $70^{\circ} \mathrm{C}$ catalyzed by NBA, NBO, TS-1, and $X \mathrm{Nb} /$ TS-1.

is, after 1, 2, 4, and 24 hours of reaction time, respectively. These finding may relate to the amount of Brønsted acid sites in the catalysts, in which the higher concentration of Brønsted sites, the higher probability of 1,2-epoxyoctane to convert to 1,2-octanediol at these sites. Furthermore, the turnover frequency (TOF) decreases about half from sample $3 \mathrm{Nb} / \mathrm{TS}-1$ to samples $10 \mathrm{Nb} / \mathrm{TS}-1$ and $20 \mathrm{Nb} / \mathrm{TS}-1$ (Table 4 ). It suggests that the Brønsted acid site in the sample $3 \mathrm{Nb} / \mathrm{TS}$ 1 is more effective compared to the other samples. It may be due to the sample $3 \mathrm{Nb} / \mathrm{TS}-1$ containing less polymerized niobium oxides species as compared to samples $10 \mathrm{Nb} / \mathrm{TS}$ 1 and $20 \mathrm{Nb} / \mathrm{TS}-1$ as observed by UV-vis DR spectroscopy. However, high selectivity of 1,2-octanediol is observed on sample containing high amount of Brønsted acid sites, that is, sample $20 \mathrm{Nb} / \mathrm{TS}-1$.

\section{Conclusions}

Impregnation of niobic acid onto titanium silicalite resulted in the formation of Brønsted acid sites. Both the MFI structure of TS-1 and tetrahedral titanium structure still retained after impregnation of niobic acid. It was found that the niobium species has interacted with the surface hydroxyl groups of TS-1. The addition of niobic acid onto TS- 1 has resulted an increase of the catalytic activity toward the rate of formation of epoxide.

\section{Acknowledgments}

The authors gratefully acknowledge funding from The Ministry of Science Technology and Innovation Malaysia (MOSTI), under IRPA Grant no. 09-02-06-0057 SR0005/0903. Thanks to Sheela a/p Chandran for FESEM images.

\section{References}

[1] I. Nowak and M. Ziolek, "Niobium compounds: preparation, characterization, and application in heterogeneous catalysis," Chemical Reviews, vol. 99, no. 12, pp. 3603-3624, 1999.

[2] K. Tanabe, "Catalytic application of niobium compounds," Catalysis Today, vol. 78, no. 1-4, pp. 65-77, 2003.

[3] M. Ziolek, "Niobium-containing catalysts-the state of the art," Catalysis Today, vol. 78, no. 1-4, pp. 47-64, 2003.

[4] K. Tanabe and S. Okazaki, "Various reactions catalyzed by niobium compounds and materials," Applied Catalysis A, vol. 133, no. 2, pp. 191-218, 1995.

[5] T. Iizuka, S. Fujie, T. Ushikubo, Z. Chen, and K. Tanabe, "Esterification of acrylic acid with methanol over niobic acid catalyst," Applied Catalysis, vol. 28, pp. 1-5, 1986.

[6] S. Okazaki, T. Iizuka, and S. Kado, "Solid acid catalyst of acid-treated hydrated niobium oxide and method for its preparation," US Patent 4652544, 1987.

[7] K. Tanabe, "Application of niobium oxides as catalysts," Catalysis Today, vol. 8, no. 1, pp. 1-11, 1990.

[8] T. Okuhara, "Water-tolerant solid acid catalysts," Chemical Reviews, vol. 102, no. 10, pp. 3641-3666, 2002.

[9] J.-M. Jehng and I. E. Wachs, "Molecular design of supported niobium oxide catalysts," Catalysis Today, vol. 16, no. 3-4, pp. 417-426, 1993.

[10] N. Ichikuni, M. Shirai, and Y. Iwasawa, "Surface structures and catalytic properties of supported niobium oxides," Catalysis Today, vol. 28, no. 1-2, pp. 49-58, 1996.

[11] X. Gao, I. E. Wachs, M. S. Wong, and J. Y. Ying, "Structural and reactivity properties of $\mathrm{Nb}-\mathrm{MCM}-41$ : comparison with that of highly dispersed $\mathrm{Nb}_{2} \mathrm{O}_{5} / \mathrm{SiO}_{2}$ catalysts," Journal of Catalysis, vol. 203, no. 1, pp. 18-24, 2001. 
[12] V. S. Braga, J. A. Dias, S. C. L. Dias, and J. L. de Macedo, "Catalyst materials based on $\mathrm{Nb}_{2} \mathrm{O}_{5}$ supported on $\mathrm{SiO}_{2}-\mathrm{Al}_{2} \mathrm{O}_{3}$ : preparation and structural characterization," Chemistry of Materials, vol. 17, no. 3, pp. 690-695, 2005.

[13] J.-M. Jehng and I. E. Wachs, "The molecular structures and reactivity of supported niobium oxide catalysts," Catalysis Today, vol. 8, no. 1, pp. 37-55, 1990.

[14] J.-M. Jehng and I. E. Wachs, "Molecular structures of supported niobium oxide catalysts under ambient conditions," Journal of Molecular Catalysis, vol. 67, no. 3, pp. 369-387, 1991.

[15] M. Shirai, N. Ichikuni, K. Asakura, and Y. Iwasawa, "Preparations and catalytic properties of single, pair, and monolayer niobium catalysts," Catalysis Today, vol. 8, no. 1, pp. 57-66, 1990.

[16] N. K. Mal, A. Bhaumik, P. Kumar, and M. Fujiwara, "Microporous niobium phosphates and catalytic properties prepared by a supramolecular templating mechanism," Chemical Communications, vol. 9, no. 7, pp. 872-873, 2003.

[17] N. K. Mal, A. Bhaumik, M. Fujiwara, and M. Matsukata, "Novel organic-inorganic hybrid and organic-free mesoporous niobium oxophosphate synthesized in the presence of an anionic surfactant," Microporous and Mesoporous Materials, vol. 93, no. 1-3, pp. 40-45, 2006.

[18] D. Prasetyoko, Z. Ramli, S. Endud, and H. Nur, "Preparation and characterization of bifunctional oxidative and acidic catalysts $\mathrm{Nb}_{2} \mathrm{O}_{5} / \mathrm{TS}-1$ for synthesis of diols," Materials Chemistry and Physics, vol. 93, no. 2-3, pp. 443-449, 2005.

[19] M. Taramasso, G. Perego, and B. Notari, "In 1983, trace levels of tetrahedral Ti(IV) were reported in a ZSM-5 analog," US Patents 4410501, 1983.

[20] E. I. Ko and J. G. Weissman, "Structures of niobium pentoxide and their implications on chemical behavior," Catalysis Today, vol. 8, no. 1, pp. 27-36, 1990.

[21] M. Paulis, M. Martín, D. B. Soria, A. Díaz, J. A. Odriozola, and M. Montes, "Preparation and characterization of niobium oxide for the catalytic aldol condensation of acetone," Applied Catalysis A, vol. 180, no. 1-2, pp. 411-420, 1999.

[22] T. Armaroli, G. Busca, C. Carlini, M. Giuttari, A. M. R. Galletti, and G. Sbrana, "Acid sites characterization of niobium phosphate catalysts and their activity in fructose dehydration to 5-hydroxymethyl-2-furaldehyde," Journal of Molecular Catalysis A, vol. 151, no. 1-2, pp. 233-243, 2000.

[23] J. M. R. Gallo, I. S. Paulino, and U. Schuchardt, "Cyclooctene epoxidation using Nb-MCM-41 and Ti-MCM-41 synthesized at room temperature," Applied Catalysis A, vol. 266, no. 2, pp. 223-227, 2004.

[24] T. Tanaka, T. Yoshida, H. Yoshida, et al., "XAFS study of niobium oxide on alumina," Catalysis Today, vol. 28, no. 1-2, pp. 71-78, 1996.

[25] E. B. Pereira, M. M. Pereira, Y. L. Lam, C. A. C. Perez, and M. Schmal, "Synthesis and characterization of niobium oxide layers on silica and the interaction with nickel," Applied Catalysis A, vol. 197, no. 1, pp. 99-106, 2000.

[26] K. Asakura and Y. Iwasawa, "Synthesis, characterization, and catalytic properties of $\mathrm{SiO}_{2}$-attached one-atomic-layer niobium oxide catalysts," Journal of Physical Chemistry, vol. 95, no. 4, pp. 1711-1716, 1991.

[27] F. M. T. Mendes, C. A. Perez, R. R. Soares, F. B. Noronha, and M. Schmal, "Ammonium complex of niobium as a precursor for the preparation of $\mathrm{Nb}_{2} \mathrm{O}_{5} / \mathrm{Al}_{2} \mathrm{O}_{3}$ catalysts," Catalysis Today, vol. 78, no. 1-4, pp. 449-458, 2003.
[28] I. Ahmad, T. J. Dines, J. A. Anderson, and C. H. Rochester, "Fourier-transform infrared study of the adsorption of acetophenones on niobic acid," Spectrochimica Acta Part A, vol. 55, no. 2, pp. 397-409, 1999.

[29] M. Morais, E. F. Torres, L. M. P. M. Carmo, et al., "Benzylation of toluene and anisole by benzyl alcohol catalysed by niobic acid," Catalysis Today, vol. 28, no. 1-2, pp. 17-21, 1996.

[30] C. L. T. da Silva, V. L. L. Camorim, J. L. Zotin, M. L. R. D. Pereira, and A. da Costa Faro Jr., "Surface acidic properties of alumina-supported niobia prepared by chemical vapour deposition and hydrolysis of niobium pentachloride," Catalysis Today, vol. 57, no. 3-4, pp. 209-217, 2000.

[31] T. Hanaoka, K. Takeuchi, T. Matsuzaki, and Y. Sugi, "Niobic acid as a solid acid catalyst for ring-opening reactions of phenyloxirane," Catalysis Today, vol. 8, no. 1, pp. 123-132, 1990.

[32] P. Batamack, R. Vincent, and J. Fraissard, "The acidity of niobic acid studied by ${ }^{1} \mathrm{H}$ broad-line NMR at $4 \mathrm{~K}$ and $1 \mathrm{H}$ MAS NMR at room temperature: comparison with other solid acids," Catalysis Today, vol. 28, no. 1-2, pp. 31-39, 1996.

[33] Y. Gushikem and S. S. Rosatto, "Metal oxide thin films grafted on silica gel surfaces: recent advances on the analytical application of these materials," Journal of the Brazilian Chemical Society, vol. 12, no. 6, pp. 695-705, 2001.

[34] S. Damyanova, L. Dimitrov, L. Petrov, and P. Grange, "Effect of niobium on the surface properties of $\mathrm{Nb}_{2} \mathrm{O}_{5}-\mathrm{SiO}_{2}$-supported Mo catalysts," Applied Surface Science, vol. 214, no. 1-4, pp. 68-74, 2003.

[35] F. B. Noronha, A. Frydman, D. A. G. Aranda, et al., "The promoting effect of noble metal addition on niobia-supported cobalt catalysts," Catalysis Today, vol. 28, no. 1-2, pp. 147-157, 1996.

[36] H. J. M. Bosman, A. P. Pijpers, and A. W. M. A. Jaspers, "An $\mathrm{X}$-ray photoelectron spectroscopy study of the acidity of $\mathrm{SiO}_{2}$ $\mathrm{ZrO}_{2}$ mixed oxides," Journal of Catalysis, vol. 161, no. 2, pp. 551-559, 1996.

[37] J.-M. Jehng, H. Hu, X. Gao, and I. E. Wachs, "The dynamic states of silica-supported metal oxide catalysts during methanol oxidation," Catalysis Today, vol. 28, no. 4, pp. 335350, 1996.

[38] C. Resini, M. Panizza, F. Raccoli, et al., "Oxidation of ethane and cyclohexane over vanadia-niobia-silica catalysts," Applied Catalysis A, vol. 251, no. 1, pp. 29-38, 2003.

[39] I. E. Wachs, J.-M. Jehng, G. Deo, H. Hu, and N. Arora, "Redox properties of niobium oxide catalysts," Catalysis Today, vol. 28, no. 1-2, pp. 199-205, 1996.

[40] J. C. Védrine, G. Coudurier, A. Ouqour, P. G. Pries de Oliveira, and J. C. Volta, "Niobium oxide based materials as catalysts for acidic and partial oxidation type reactions," Catalysis Today, vol. 28, no. 1-2, pp. 3-15, 1996.

[41] M. Ziolek, I. Sobczak, A. Lewandowska, et al., "Oxidative properties of niobium-containing mesoporous silica catalysts," Catalysis Today, vol. 70, no. 1-3, pp. 169-181, 2001.

[42] I. Nowak, B. Kilos, M. Ziolek, and A. Lewandowska, "Epoxidation of cyclohexene on Nb-containing meso- and macroporous materials," Catalysis Today, vol. 78, no. 1-4, pp. 487498, 2003.

[43] B. Kilos, M. Aouine, I. Nowak, M. Ziolek, and J. C. Volta, “The role of niobium in the gas- and liquid-phase oxidation on metallosilicate MCM-41-type materials," Journal of Catalysis, vol. 224, no. 2, pp. 314-325, 2004. 
[44] I. Nowak and M. Ziolek, "Effect of texture and structure on the catalytic activity of mesoporous niobosilicates for the oxidation of cyclohexene," Microporous and Mesoporous Materials, vol. 78, no. 2-3, pp. 281-288, 2005.

[45] D. Srinivas, P. Manikandan, S. C. Laha, R. Kumar, and P. Ratnasamy, "Reactive oxo-titanium species in titanosilicate molecular sieves: EPR investigations and structure-activity correlations," Journal of Catalysis, vol. 217, no. 1, pp. 160-171, 2003.

[46] F. Bonino, A. Damin, G. Ricchiardi, et al., "Ti-Peroxo Species in the TS- $1 / \mathrm{H}_{2} \mathrm{O}_{2} / \mathrm{H}_{2} \mathrm{O}$ System," The Journal of Physical Chemistry B, vol. 108, no. 11, pp. 3573-3583, 2004.

[47] A. Bhaumik and T. Tatsumi, "Intramolecular rearrangement of epoxides generatedin situover titanium silicate molecular sieves," Journal of Catalysis, vol. 182, no. 2, pp. 349-356, 1999. 

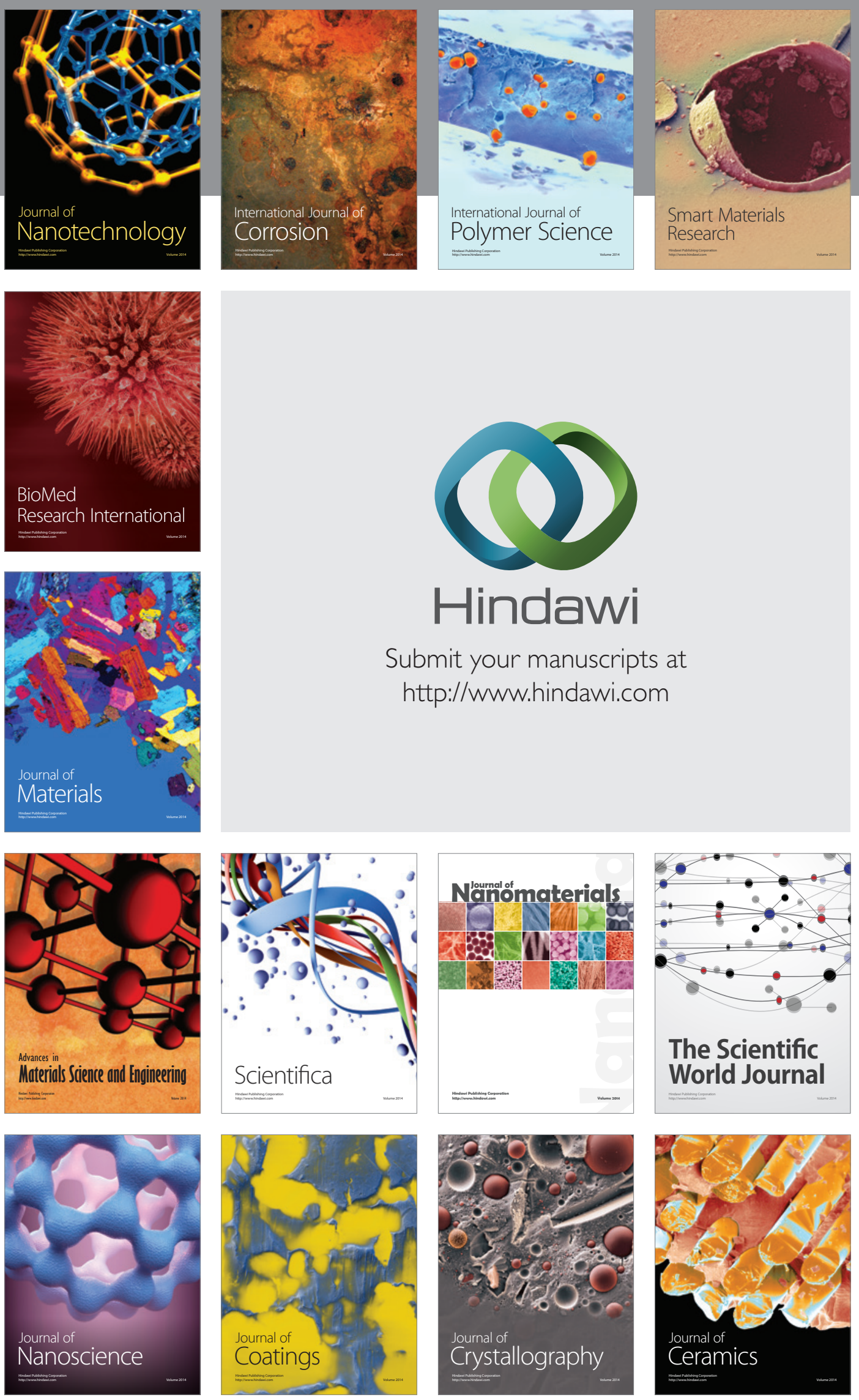

The Scientific World Journal

Submit your manuscripts at

http://www.hindawi.com

\section{World Journal}



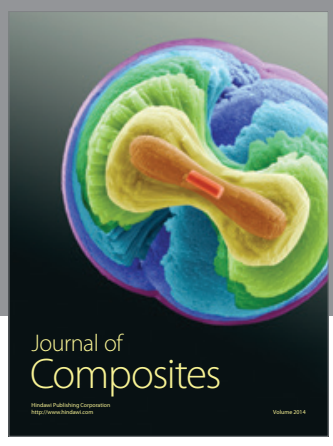
